\title{
THE IMPORTANCE AND NECESSITY OF TEACHING COMPUTER SCIENCE AND PROGRAMMING FOR PRIMARY SCHOOL STUDENTS
}

\author{
Bahromova Muhayyo Mansurjon qizi \\ Lecturer, Namangan State University, Namangan, Uzbekistan
}

\section{ABSTRACT}

The article highlights the importance and objective necessity of teaching computer science and programming to primary school students in the progress of the country's education system at the current stage of development. Furthermore, it outlines the specifics of computer literacy and skills development for primary school students in the context of the development of the digital economy. The article describes that in a developing information society, the basis of social development is not only traditional opportunities, but also people's ability, initiative, creative approach to work, intellectual activity, independent improvement of their knowledge and skills, and, at the same time, the processes of storing, transmitting and receiving large amounts of data are the biggest impetus for the development of computer technology in various fields of human activity.

KEYWORDS:- Digital economy, education system, computer, technology, informatics, programming, programming elements, primary education, information, algorithm, program, science, innovation.

\section{INTRODUCTION}

It is known that young generation are an important subject of socio-political, economic, cultural and spiritual renewal of society to stimulate development and influence the processes taking place in life, and it is important to bring them up as harmoniously developed individuals. The future of any society is determined by the level of development of its education system, which is an integral part of it and a vital necessity. Today, the reform and improvement of the system of continuing education in our country, which is on the path of independent development, raising it to a new level, the introduction of advanced pedagogical and information technologies and improving the efficiency of education has risen to the level of state policy. With the adoption of the Law "On Education" and the "On the National Training
Program" in the Republic of Uzbekistan, the basis for modern training through the system of continuing education has been created.

Present socio-economic reforms are being implemented by paying special attention to the development of the education system. In particular, the Decree of the President of the Republic of Uzbekistan dated February 7, 2017, № PD-4947 "On the Action Strategy for five priority areas of further development of the Republic of Uzbekistan for 2017-2021s", also includes further improvement of the system of continuing education, increasing the capacity of quality educational services, continuing the policy of training highly qualified personnel in line with modern needs of the labor market, radically improving the quality of general secondary education, in-depth study of foreign languages, computer science and other important and demanding sciences such as 
CURRENT RESEARCH JOURNAL OF PEDAGOGICS 2(9): 192-196,

September 2021 DOI: https://doi.org/10.37547/pedagogics-crjp-02-09-40

ISSN 2767-3278

(C)2021 Master Journals

\section{Crossref do) 8 Google}

Accepted 25 $5^{\text {th }}$ September, 2021 \& Published $30^{\text {th }}$ September, 2021

mathematics, physics, chemistry, biology, as well as other important tasks [1].

Also, the Presidential Decree № PD-5712 “On approval of the Concept of development of higher education system of the Republic of Uzbekistan until 2030" dated April 29, 2019, the Presidential Decree № PD-6108 "On measures to develop education and science in the new period of development of Uzbekistan" dated November 6, 2020, the Presidential Decree № PD-4884 “On additional measures for further improvement of the education and upbringing system" dated November 6, 2020, and also the resolutions № PD-4963 "About measures for support of research activities and implementation of system of continuous professional development in the field of national education" dated January 25, 2021 and other regulations related to this activity determine the relevance of the research.

At the current time, it is complicated to imagine starting a business in any field and managing it without a computer. To be a literate person in the 21st century, it is needed to be computer literate and have a good command of information technology. Every professional, regardless of the field in which he works, must know and work with the means of information production and methods of their use in order to perform their duties at the level of modern requirements. That is why at present, the radical reforms in the field of education in our independent Republic, including the "National Training Program", it is emphasized: "It is aimed to restructure the system and content of training personnel based on the prospects of social and economic development of the country, the needs of society, modern achievements in science, culture, engineering and technology".

At present, a comprehensive study of the factors and the mechanism of influencing the pedagogical principles of ICT application, its psychological features and cognitive process, or how effective it is to use ICT in full or in part of a subject in general secondary education, as well as many other aspects, is becoming relevant.

Electronic information-educational resourcesprograms have been created for educational institutions, which serve as a training ground for teachers on the use of modern techniques. This will assist teachers to better organize the lessons and improve their skills. The work on creation, development and popularization of multimedia programs is bearing fruit. In educational institutions, students are learning about science directly on the Internet or in classrooms using discs and audio discs. Nowadays, the ranks of our young generation, who are able to use modern information technologies and amaze the world with their potential, are growing. All this is the result of the creation of favorable conditions and opportunities for young people in our country.

It is known for all that the XXI century is the age of globalization, the century of technology. Currently, science and technology are evolving rapidly, which is requiring the use of new technologies. It is important to increase the effectiveness of lessons, the effective use of new technologies, knowing that every educator is responsible for the education of our future youth a highly cultured and well-educated.

The school serves as a foundation for students to learn. For this reason, schools are provided with the necessary equipment for interactive teaching of computer science, English and similar subjects, for example, computers and interactive whiteboards. These days, it is necessary to use pedagogical technologies effectively to attract students' attention to computer science. In order to increase the effectiveness of education, it is advisable to pay more attention to the student in the classroom in individual manner.

Involving primary school students in the process of learning the elements of computer science and programming is a strategic task in all education 
CURRENT RESEARCH JOURNAL OF PEDAGOGICS 2(9): 192-196,

September 2021 DOI: https://doi.org/10.37547/pedagogics-crjp-02-09-40

ISSN 2767-3278

(C)2021 Master Journals

\section{Crossref do) 8 Google}

Accepted 25 $5^{\text {th }}$ September, 2021 \& Published 30 ${ }^{\text {th }}$ September, 2021

systems aimed at learning the basics of computer science. The insufficiency of the didactic and research work on teaching computer science education from primary school, teaching aids, scientific-methodical articles and their age and psychophysiological features, as well as sanitaryhygienic rules, and pedagogical software developed in accordance with the technical requirements, requires further in-depth study of this topic. The computer science education in primary school can be justified as an experiment on the introduction of new information technologies in primary school, aimed at forming the basis of fundamental knowledge and methods of work that will contribute to the effective mastery of computer science education in the future.

Development of various educational programs aimed at informatization of society and teaching informatics in the stages of continuing education, and the development of informatics as much as possible in an environment where education should focus on informatics from the lower levels - evaluation is appropriate.

In a developing information society, the basis of social development is not only traditional opportunities, but also people's ability, initiative, creative approach to work, intellectual activity, independent improvement of their knowledge and skills, and, at the same time, the processes of storing, transmitting and receiving large amounts of data are the biggest impetus for the development of computer technology in various fields of human activity.

Therefore, the informatization of the general secondary education system should be considered in the broadest sense as the provision of education with the practice of effective use and creation of new information technology tools aimed at methodological, psychological and pedagogical implementation of teaching objectives. The pedagogical objectives of the use of computer technology in the primary school should be reflected in the following, that is a computer is:

- The object of study of computer science;

- A tool that increases the effectiveness of the learning process;

- A tool for teaching various subjects;

- A tool for monitoring and evaluation;

- A means of interaction;

- A tool of educational modeling;

- A means of educational activity;

- A component of the pedagogical management system;

- Application in the field of defectology;

- A tool of technical creativity.

Induction and deduction, generalization and definition, analysis and synthesis, classification and systematization, abstraction and simulation are among the methods and techniques of student thinking in the process of teaching using computers and their tools. This serves as a for the expression, substantiation and proof of ideas to draw logical conclusions, and on this basis for the growth of logical thinking.

The use of software in the primary school curriculum should directly support the universal activities of students. As for the software used in education today, it includes various text and graphics editors, spreadsheets, database management systems, and more.

In case these software tools provide the ability to write, compute and draw correctly, to exchange ideas at this stage of education, it satisfies the learning process in all respects, and enables to deepen the use of new information technologies in later stages of education.

The introduction of new information technologies is associated with the development 
CURRENT RESEARCH JOURNAL OF PEDAGOGICS 2(9): 192-196,

September 2021 DOI: https://doi.org/10.37547/pedagogics-crjp-02-09-40

ISSN 2767-3278

(C)2021 Master Journals

Crossref do: 81 Google

Accepted 25th September, 2021 \& Published 30 ${ }^{\text {th }}$ September, 2021

of a number of other software tools that facilitate the educational process. Examples of such programs are training, testing, virtual demonstration, simulation, control and other programs. Their direct application allows the use of computers as a tool to solve traditional didactic problems.

The introduction of modern pedagogical technologies using computers can significantly increase the cognitive activity of students. The computer attracts students with its great potential as an object of learning.

For primary school students, computer technology itself is a novelty, and mastering its capabilities and skills and interest in learning to work with it, can be a good factor for their learning and development process. Although computer science is in the process of becoming a scientific fundamental and educational science, it, like other basic sciences, provides the formation of universal mental abilities of students.

Therefore, it is advisable to introduce computer science education in primary school. From our point of view, the development of software in this area will determine its practical application in various disciplines. In order to increase the effectiveness of computer science lessons, it is necessary to use information and communication technologies, create conditions for teachers to compose virtual lectures, experimental stands, which are the most effective methods and means of communication, and use them in the classroom. It allows to gain new knowledge and solve a variety of problems. At the same time, it assesses the level of training of teachers at the undergraduate level, selects problems according to the purpose of training, provides informational and programmatic support in solving them, receives, analyzes and evaluates their answers.

This principle of innovative educational technologies creates a series of devices that control the cognitive activity of teachers. The educator creates initial guidelines for mastering the topic and, in case of need, provides them with individual assistance, in collaboration with a methodist specialist, develops a program for mastering the topic with the help of a computer. Modern information technologies open up endless possibilities for teachers to access nontraditional sources of information, increase the efficiency of independent work, provide completely new opportunities for creativity, creation and strengthening of various professional skills, and allows the implementation of new forms and methods of teaching through using tools to create conceptual and mathematical models of events and processes.

\section{ReFERENCES}

1. The Decree of the President of the Republic of Uzbekistan dated February 7, 2017, № PD4947 "On the Action Strategy for five priority areas of further development of the Republic of Uzbekistan for 2017-2021s"

2. Begimkulov U.Sh., Djuraev R.X., Isyanov R.G., Sharipov Sh.S., Adashboev Sh.M., Soy M.N. "Informatization of pedagogical education: theory and practice", Tashkent: - 2011.

3. Qayumova N.A. "The conditions of the information-educational system of education and the training of teachers in the field of information and communication technologies". Monograph. Tashkent. Science and Technology, 2015. 192 pages.

4. Begimkulov U.Sh. "Organization of pedagogical education in the environment of modern information technologies". Journal of Pedagogical Education, № 1, 2004 - 25-25 pages

5. Ushakov D.M., Yurkov T.A. "Pascal for 
CURRENT RESEARCH JOURNAL OF PEDAGOGICS 2(9): 192-196,

September 2021 DOI: https://doi.org/10.37547/pedagogics-crjp-02-09-40

ISSN 2767-3278

(C)2021 Master Journals

Crossref dof 81 Google

Accepted 25 $5^{\text {th }}$ September, 2021 \& Published 30 $0^{\text {th }}$ September, 2021

schoolchildren". Moscow-SanktPeterburgNizhny Novgorod - Voronezh - Rostov-onDon - Ekaterinburg - Samara - Novosibirsk Kiev - Kharkiv - Minsk 2010

6. Isoqov I., Kulmamatov S.I. Texts of lectures on "Innovative technologies in teaching computer science", Gulistan, 2014. 